\title{
DEVELOPING OF INSTRUCTIONAL MEDIA-BASED ANIMATION VIDEO ON ENZYME AND METABOLISM MATERIAL IN SENIOR HIGH SCHOOL
}

\author{
Muhammad Mustofa Yusuf*, Mohamad Amin, and Nugrahaningsih \\ Department of Biology, State University of Malang, Indonesia \\ *corresponding e-mail: mmustofayusuf@yahoo.co.id
}

\begin{abstract}
The research aimed to product a learning material related to animation video on enzyme and metabolism material for high school student which is validated by media and material experts, educational practition and student legibility. Research and development model is ADDIE with quantitative-qualitative data analyzing methode. Data collection was obtained from validation results by media and material experts, educational partition and student legibility. The validation results were scores and suggestion. The percentage of product from expert media validation (100\%), expert material validation (89,58\%), educational practition $(84,61 \%)$, and student legibility $(81,91 \%)$ showed valid of the criteria and feasible to use after revision.
\end{abstract}

Keywords: animation video,instructional media, learning material.

C 2017 Department of Biology Education, FTTE, University of Muhammadiyah Malang, Indonesia

\section{INTRODUCTION}

Biology, according to education curriculum in Indonesia, must be given to students to accommodate learning activities with a systematic step through scientific approach. Those approach should be supported by interactive learning process, as stated in Minister of Education and Culture Decree No. 24 of 2016 on Process Standards that the learning process should be interactive, inspiring, fun, challenging, motivating learners to participate actively, and providing sufficient space for initiative, creativity and independence in accordance with talent, interest, and learner physical and psychological development.

Learning material, as subject matter that is systematically arranged to be used by teachers in learning (Maryani, 2009), is one of the learning tools that can support the process standard of curriculum. Due to the current technological developments, learning materials used must be able to accommodate printed materials and digital materials. Effectiveness of digital material is better than the textbook in learning (Suartama, 2010). Digital material combine the computer program consisted of texts, graphic, sound and images and animations (Hamidi, et al., 2011; Islam, et al.,
2014). Students are already familiar with using the computer, internet and many of the software programs. Teacher must be utilizing this technology to enhance the learning process in the class. Hence innovation-based digital materials in learning must be conducted to support education.

Preliminary analysis of learning material needed in one of senior high school in Malang shows that: a) each class has adequate facilities for learning (LCD, projector screen, power point or video slide, sound speaker, table and chair for each student), b) students requires visualization in some concept, such as enzyme and cell metabolism material $(40 \%$ of students have score under the minimum criteria on those topic), c) $79.16 \%$ students have difficulties to study enzyme material and cell metabolism. Therefore development of media to support learning activities is important, such us using video and animation.

Video provides more flexible media to support students learning activities, able to explain concept related to mechanism or process, can be repeated and stopped according to the students need (Hwang, et al., 2012; Lashari, et al., 2013; Rudi \& Riyana, 2009; Soika, et al., 2010). Video can also engage the students' attention in class, clarify the idea and 
illustrate the concept so that students can get long term memory of the material (Cardoso, et al., 2009; Moreno \& Ortegano-Layne, 2008). Economically, video relatively cheaper than printed materials both in price and in operation (Putri, 2012). One kind of good video in learning is animation. Animation videos can enrich students' experience and competence on a variety of learning materials (Ainsworth, 2008; Brenton et al., 2007; Harrison \& Hummell, 2010; Rootman \& Gordon-ElBihbety, 2008; Salim \& Tiawa, 2014). Along with technological development, animated video is able to provide a stronger visual appearance of various phenomena and abstract information to improve the quality of learning process and learning outcomes (Hegarty, 2004).

Regarding to that situation, research on developing of instructional media-based animation video as a learning material is needed to be established. The research aimed to product a learning material related to animation video on enzyme and metabolism material for high school student which is validated by media and material experts, educational partition and student legibility.

\section{METHOD}

Research and development model is ADDIE with quantitative-qualitative data analysing method. According to (McGriff, 2000) ADDIE model consists of five main stages: Analysis, Design, Development or Production, Implementation or Delivery and Evaluations. Analysis stage is the process of defining what is to be learned. Design stage is the process of specifying how it is to be learned. Development stage is the process of authoring and producing the materials. Implementation stage is the process of installing the project in the real world context. Evaluation stage is the process of determining the adequacy of the instruction.

This development model procedure was chosen because it has systematic and appropriate steps used to develop learning products, such as media-based animation video. Data collection was obtained from validation results by media and material experts, educational partition and student legibility. Validators were biology lecturer as media and material experts, field partition is biology teacher of SMA Negeri 3 Malang, and students grade XII IPA 5 as trial subject for product legibility to determine the validity of the product.

\section{RESULTS AND DISCUSSION}

In the analysis stage, there was problem identification process that students require visualization in enzyme and cell metabolism material. Besides, $79.16 \%$ students have difficulties to study enzyme material and cell metabolism. Hence, the development of interactive media related to enzyme and cell metabolism is needed.

In the design stage, there was planning to develop the media-based animation video which may help student understand the material easily. Furthermore in the development stage the media was construct with six main menu scenarios: 1) Basic Competencies related to enzyme and cell metabolism material, 2) elaboration of basic competencies as the scope of the material in the video; 3) materials as a discussion in the class and self-supporting materials for each student, consist of enzymes, catabolism and anabolism; 4) author profile; 5) quiz; and 6) bibliography.

Moreover in the implementation stage is the validation process of media by media and material experts, educational partition and student legibility. Then in the evaluation stage is the process of determining the adequacy of the media instruction by analysing the result of validation. The validation results showed that product is valid. The percentage of product validation is $100 \%$ from expert media (with addition of quiz as a suggestion), $89.85 \%$ from expert material (with revision of operational verb used), $84.61 \%$ from educational partition (with addition of basic competencies at the beginning of video as a suggestion), and $84.61 \%$ from student legibility (with enlargement of text font and attributed with music as suggestion).

Based on data analysis, instructional mediabased animation video is valid and feasible to use after revision. Animation video has many advantages as expressed by validators, educational partition and students, include 1) giving innovations in learning, 2) attractive design 3) clear and concise material texts, 4) easy operation, 5) more interesting and easy to understand. Students also revealed that studying enzyme material and cell metabolism through video animation is more attractive than using book, because it is able to provide a visual 
appearance of various phenomena and abstract information that lead to improvement of learning process and learning outcomes (Anjarwati, et al., 2016; Hegarty, 2004; Kennewell \& Beauchamp, 2007; Paik \& Schraw, 2013).

Students become more interested in studying enzyme and cell metabolism using animation video, as stated by (Saragih, 2012) and (Nugroho, 2015) that video used in learning can improve students' learning motivation. Increasing of learning motivation in students is a good indicator to improve the learning process and learning outcomes ((Leow, 2014; Pruneski \& Donovan, 2007). Animation video in learning material is more efficient to conduct in the class. Teachers can assign tasks to students to study enzyme material and cell metabolism independently using the animation video.

The developed animation video in this study can run by laptop or computer with Windows, Linux, and Android operating system, so that teachers do not need to prepare many intricate teaching materials to achieve students' cognitive competence. By utilizing the animation video student can assess materials independently, this can be an advantage for schools that do not have a laptop facility for every student, and economically this learning material is cheaper and affordable for most schools in Indonesia. As an independent learning material, students can use this resource without limited space and time by entering animation video on laptop or gadget. For students, the availability of easily accessible and interesting learning materials will be able to be a positive motivation to continue learning in everyday life.

\section{CONCLUSION}

Based on the results of the research and development, it can be concluded that instructional media-based animation video is valid of the criteria and feasible to use after revision.

\section{REFERENCES}

Ainsworth, S. (2008). How do animations influence learning? Current Perspectives on Cognition, Learning, and Instruction: Recent Innovations in Educational Technology That Facilitate Student
Learning, 37-67.

Anjarwati, D., Winarno, A., \& Churiyah, M. (2016). Improving learning outcomes by developing instructional media-based adobe flash professional cs 5.5 on principles of business subject. IOSR Journal of Research \& Method in Education, 6(5), 1-6. https://doi.org/10.9790 /7388-0605010106

Brenton, H., Hernandez, J., Bello, F., Strutton, P., Purkayastha, S., Firth, T., \& Darzi, A. (2007). Using multimedia and web3D to enhance anatomy teaching. Computers and Education, 49(1), 32-53. https://doi.org/10. 1016/j.compedu.2005.06.005

Cardoso, D. C., Arent, C. O., \& Cristiano, M. P. (2009). Development of new didactic materials for teaching science and biology: the importance of the new education practices. OnLine Journal of Biological Sciences, 9(1), 1-5. https://doi.org/10.3844/ ojbs.2009.1.5

Hamidi, F., Kharamideh, Z. M., \& Ghorbandordinejad, F. (2011). Comparison of the training effects of interactive multimedia (CDs) and non-interactive media (films) on increasing learning speed, accuracy and memorization in biological science course. Procedia Computer Science, 3, 144-148. https://doi.org/10.1016/j.procs. 2010.12.025

Harrison, H. L., \& Hummell, L. J. (2010). Incorporating animation concepts and principles in STEM education. Technology Teacher, 69(8), 20-25. Retrieved from https://eric.ed.gov/?id=EJ887817

Hegarty, M. (2004). Dynamic visualizations and learning: Getting to the difficult questions. Learning and Instruction, 14, 343-351.

Hwang, I., Tam, M., Lam, S. L., \& Lam, P. (2012). Review of use of animation as a supplementary learning material of physiology content. The Electronic Journal of E-Learning Volume, 10(4), 368-377.

Islam, M. B., Ahmed, A., Islam, M. K., \& Shamsuddin, A. K. (2014). Child education through animation: an experimental study. International Journal of Computer Graphics \& Animation, 4(4), 43-52. https://doi.org/ http://dx.doi.org/10.5121/ijcga.2014.4404

Kennewell, S., \& Beauchamp, G. (2007). The features of interactive whiteboards and their influence on learning. Learning, Media and Technology, 32(3), 227-241. https://doi.org/ $10.1080 / 17439880701511073$ 
Lashari, T. A., Alias, M., Kesot, M. J., \& Akasah, Z. A. (2013). An affective-cognitive teaching and learning approach for enhanced behavioural engagements among engineering students. Engineering Education, 8(2), 65-76. https://doi.org/10.11120/ened.2013. 00011

Leow, M. F. (2014). Interactive multimedia learning: Innovating classroom education in a Malaysian University. The Turkish Online Journal of Educational Technology, 13(2), 99-110.

Maryani, S. (2009). Pengembangan bahan ajar berbasis multimedia interaktif mata kuliah komputerisasi akuntansi (Studi kasus: myob accounting 17 pada modul banking). Retrieved from http://www.gunadarma.ac.id

McGriff, S. J. (2000). Instructional System Design (ISD): Using the ADDIE Model. Retrieved from https://www.lib.purdue. edu/sites/default/files/directory/butler38/AD DIE.pdf

Moreno, R., \& Ortegano-Layne, L. (2008). Do classroom exemplars promote the application of principles in teacher education? A comparison of videos, animations, and narratives. Educational Technology Research and Development, 56(4), 449-465. https://doi.org/10.1007/ s11423-006-9027-0

Nugroho, A. (2015). Pengaruh penggunaan media pembelajaran berbasis power point dengan video dan animasi terhadap motivasi belajar dan prestasi belajar pada materi perawatan unit kopling siswa kelas 2 Jurusan Teknik Kendaraan Ringan SMK Piri 1 Yogyakarta. Universitas Negeri Yogyakarta.

Paik, E. S., \& Schraw, G. (2013). Learning with animation and illusions of understanding. Journal of Educational Psychology, 105(2), 278-289. https://doi.org/10.1037/a0030281

Pruneski, J., \& Donovan, S. (2007). The use of animations in undergraduate biology education: Going beyond the content!, (937791), 937791.

Putri, N. (2012). Efektifitas penggunaan media video untuk meningkatkan pengenalan alat musik daerah pada pembelajaran IPS bagi anak tunagrahita ringan di SDLB 20 Kota Solok. Jurnal Ilmiah Pendidikan Khusus, l(12).

Rootman, I., \& Gordon-El-Bihbety, D. (2008). A vision for a health literate canada: report of the expert panel on health literacy. Retrieved from http://www.cpha.ca/uploads/ portals/h-1/report_e.pdf

Rudi, S., \& Riyana, C. (2009). Media pembelajaran: Hakikat pengembangan, pemanfaatan, dan penilaian. Bandung: CV Wacana Prima.

Salim, K., \& Tiawa, D. H. (2014). Development of media-based learning animation for mathematics courses in Electrical Engineering, University Riau Kepulauan. International Journal of Advanced Research in Computer and Communication Engineering, 3(10), 8332-8336.

Saragih, L. (2012). Pengaruh penggunaan video pembelajaran terhadap motivasi belajar siswa pada pembelajaran sistem injeksi bahan bakar diesel kelas XI Jurusan Teknik Kendaraan Ringan SMK Piri Yogyakarta. Universitas Negeri Yogyakarta.

Soika, K., Reiska, P., \& Mikser, R. (2010). The importance of animation as a visual method in learning chemistry. Concept Maps: Making Learning Meaningful, 3(10), 9. Retrieved from http://cmc.ihmc.us/cmc2010 papers/cmc2010-b12.pdf

Suartama, I. K. (2010). Pengembangan mutimedia untuk meningkatkan kualitas pembelajaran pada mata kuliah media pembelajaran. Jurnal Pendidikan Dan Pengajaran, 43(3), 253-260. 